\title{
Potensi Penggunaan Dua Spesies Agave untuk Pembuatan Pulp dan Kertas
}

\author{
Arini Hidayati Jamil a,", Heronimus Judi Tjahjono ${ }^{\text {b, }}$ Parnidia ${ }^{a}$, Marjania \\ aBalai Penelitian Tanaman Pemanis dan Serat, Jl. Raya Karangploso 199, Malang, Indonesia

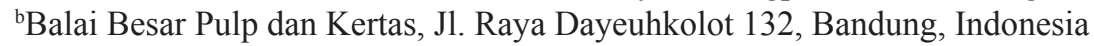

Diterima : 07 Maret 2018, Revisi akhir : 03 Mei 2018, Disetujui terbit : 07 Mei 2018

Potential of Two Agave Species for Pulp and Paper Making

\begin{abstract}
Both of Agave sisalana and A. cantala are the most favorite agave species for fiber producer plant in Indonesia. Nevertheless, research study for using fiber of A. sisalana and A. cantala for pulp and paper purpose is hard to find. This study aims to observe the characteristics of A. sisalana and A. cantala fibers as a raw material of pulp including fiber morphology, chemical components, pulp characteristics, optical and physical properties of the handsheets. The observation of all characters was based on Indonesian National Standard (SNI). The pulping method used both of soda process with 18\% active alkali and kraft process with $18 \%$ active alkali and $25 \%$ sulfidity. The result of the study for the handsheets from A. sisalana and A. cantala fibers shows that the brightness, dirt, and tear index were fulfilled to SNI standard for NBKP while the tensile index and burst index just fulfilled to SNI standard for LBKP. The handsheet of A. sisalana fiber has a higher tear index, tensile index, and burst index than the A. cantala ones. Soda pulping of both agave species resulting higher pulp yield, cellulose polymerization degrees and physical properties than kraft pulping.
\end{abstract}

Keywords : Agave sisalana, A. cantala, characteristics of the fiber, pulp

\begin{abstract}
Abstrak
Agave sisalana dan A. cantala merupakan dua spesies agave yang paling banyak dibudidayakan di Indonesia sebagai tanaman penghasil serat alam. Namun penelitian mengenai fungsi serat $A$. sisalana dan $A$. cantala sebagai bahan baku pulp dan kertas masih sulit ditemukan. Tujuan dari penelitian ini adalah mempelajari karakteristik serat $A$. sisalana dan $A$. cantala sebagai bahan baku pulp yang meliputi morfologi serat, komposisi komponen kimia, karakteristik pulp, sifat optik, dan fisik lembaran pulp yang dihasilkan. Pengamatan seluruh karakter dilakukan berdasarkan Standar Nasional Indonesia. Pemasakan menggunakan metode soda dengan alkali aktif $18 \%$ dan kraft dengan alkali aktif $18 \%$ dan sulfiditas $25 \%$. Hasil pengamatan pada lembaran pulp yang dihasilkan dari serat A. sisalana dan A. cantala menunjukkan bahwa derajat cerah, noda, dan kekuatan sobek memenuhi Standar Nasional Indonesia (SNI) Pulp Kraft Putih Kayujarum (NBKP), sementara kekuatan tarik dan kekuatan retak memenuhi SNI Pulp Kraft Putih Kayudaun (LBKP). Lembaran pulp A. sisalana memiliki kekuatan sobek, tarik, dan retak lebih tinggi dibanding lembaran pulp $A$. cantala. Metode pemasakan soda pada serat kedua spesies agave tersebut menghasilkan rendemen pulp, derajat polimerisasi selulosa, dan kekuatan fisik lebih baik dibanding metode kraft.
\end{abstract}

Kata kunci : Agave sisalana, A. cantala, karakteristik serat, pulp 


\section{Pendahuluan}

Agave termasuk dalam tanaman sukulen yang tumbuh dengan baik pada kondisi iklim kering. Di Indonesia, agave banyak ditanam di Pulau Sumbawa, Pulau Madura, dan sebagian Jawa Timur. Agave mulai dibudidayakan di Indonesia pada awal abad ke-17 sebagai tanaman penghasil serat alam hingga menjadi komoditas ekspor pada awal abad ke-20 (Utomo, Dahal and Umali, 2003). Tanaman agave dapat tumbuh lebih dari 2 meter dengan jumlah daun 114 helai (Balittas, 2016) tergantung spesies dan kondisi lingkungan tumbuhnya. Spesies agave yang dibudidayakan di Indonesia sedikitnya ada dua, yaitu Agave sisalana dan Agave cantala. Perbedaan karakter tanaman kedua spesies tersebut adalah $A$. sisalana memiliki daun yang berwarna hijau tua dengan duri di bagian tepi daunnya yang berukuran besar hingga kecil bahkan tidak berduri. Sementara daun $A$. cantala berwarna hijau keabuan dengan duri yang besar dan tajam (Jamil, Parnidi and Yogi, 2017). Potensi produksi agave terutama varietas baru $A$. sisalana $\mathrm{H} 11648$ mencapai 4,7 hingga 5,9 ton serat kering per ha per tahun (Balittas and PT.SBS, 2016).

Serat agave diekstraksi dari daun agave dengan rendemen mencapai $4,9 \%$ dari berat basah daun (Balittas, 2016). Serat agave berwarna putih kekuningan, serta memiliki kekuatan dan daya tahan yang baik. Serat agave biasa digunakan sebagai bahan pembuatan tali, jaring ikan, pembungkus kabel, kerajinan tangan, karung, geotekstil, bahan baku komposit, dan pulp (Santoso, 2009). Namun informasi tentang penggunaan serat agave dalam pembuatan pulp dan kertas masih sangat terbatas. Menurut Hurter (2001), pulp serat $A$. sisalana memiliki kualitas yang sangat baik sehingga dapat digunakan untuk pembuatan beberapa kertas khusus atau untuk memperkuat kertas daur ulang.

Tujuan penelitian ini adalah untuk mengetahui karakteristik serat Agave sisalana dan A. cantala sebagai bahan baku pulp dan kertas. Pengamatan meliputi morfologi serat, komposisi komponen kimia serat, karakeristik pulp serta sifat optik dan fisik lembaran pulp yang dihasilkan.

\section{Bahan dan Metode}

Serat agave diperoleh dari tanaman Agave sisalana dan Agave cantala yang berumur 3 tahun di Kebun Percobaan Kalipare Kecamatan
Kalipare, Kabupaten Malang, milik Balai Penelitian Tanaman Pemanis dan Serat. Masingmasing spesies agave terdiri dari 2 nomor aksesi yang berbeda. Setelah ekstraksi serat menggunakan mesin dekortikator, serat dicuci menggunakan air bersih, dan dijemur di bawah sinar matahari.

Pengamatan morfologi serat meliputi panjang serat (L), diameter serat (D), tebal dinding sel (w), dan diameter lumen (1) berdasarkan SNI 01-1840-1990 - Cara uji panjang serat kayu dan bukan kayu. Nilai turunan dimensi serat yang dihitung meliputi Bilangan Runkel (2w/l), kelangsingan (L/D), kekakuan (w/D), kelemasan (1/D), dan Muhlstep ratio $\left.\left(\left(\mathrm{D}^{2}-1^{2}\right) / \mathrm{D}^{2}\right) \times 100 \%\right)$.

Analisis komponen kimia dilakukan berdasarkan SNI, mencakup kadar air (SNI 08-7070-2005 - Cara Uji Kadar Air Pulp dan Kayu dengan Metoda Pemanasan dalam Oven), holoselulosa (SNI 01-1303-1989 - Cara Uji Kadar Holoselulosa Kayu), selulosa alfa (SNI 8400:2017 - Selulosa alfa, beta dan gama dalam pulp), pentosan (SNI 14-1304-1989 - Cara Uji Kadar Pentosan dalam Kayu), lignin (SNI SNI 8429:2017 - Lignin tidak larut asam dalam kayu dan pulp), sari (SNI 14-1032:1989 - Cara uji kadar sari (ekstrak alkohol benzena) dalam pulp dan kayu), abu (SNI ISO 2144:2010 Kertas, karton dan pulp-Cara uji kadar abu pada $900^{\circ} \mathrm{C}$ ), kelarutan air panas dan air dingin (SNI 01-1305-1989 - Cara Uji Kelarutan Kayu dalam Air Dingin dan Air Panas), dan kelarutan dalam $\mathrm{NaOH}$ 1\% (SNI ISO 692:2010 - Pulp - Cara uji kelarutan dalam alkali).

Pemasakan serat agave dikerjakan menggunakan proses soda dan proses sulfat (kraft) di dalam digester yang berputar (rotary digester) dalamudara panas. Proses soda menggunakanalkali aktif $18 \%$ sementara proses kraft menggunakan alkali aktif $18 \%$ dan sulfiditas $25 \%$. Setiap pemasakan menggunakan 200 gram berat kering serat agave. Perbandingan larutan pemasakan dengan serat agave adalah 4:1. Setiap perlakuan terdiri atas 4 ulangan. Suhu yang digunakan adalah $160^{\circ} \mathrm{C}$ dengan waktu tuju 120 menit dan waktu tahan 90 menit. Serat yang telah dimasak kemudian diaduk selama 30 menit, dibilas untuk menghilangkan lindi hitam, dan disaring menggunakan saringan bergetar untuk menghilangkan serat kasar. Serat halus yang lolos saringan dihitung sebagai rendemen pulp dan dianalisis bilangan Kappa sesuai SNI ISO 302:2014 - Pulp-Cara uji bilangan Kappa. Pemutihan pulp 
dilakukan dengan proses Elemental Chlorine Free (ECF) dengan 3 tahap pemutihan.

Pulp digiling dengan variasi waktu giling hingga mencapai $300 \mathrm{mLCFS}$ (Canadian Standard Freeness). Selanjutnya pulp dibuat lembaran pulp untuk pengujian sifat fisik lembaran pulp yang terdiri atas indeks sobek (SNI ISO 1974:2016 - Kertas - Cara uji ketahanan sobek - Metode Elmendorf), indeks retak (SNI ISO 2758:2011 Kertas - Cara uji ketahanan retak), dan indeks tarik (SNI ISO 1924-2:2016 - Kertas dan karton Cara uji sifat tarik - Bagian 2: Metode kecepatan elongasi tetap $(20 \mathrm{~mm} /$ menit $))$, serta sifat optik meliputi derajat cerah (SNI ISO 2470-1:2014 Kertas, karton, dan pulp - Cara uji faktor pantul biru cahaya baur - Bagian 1: Kondisi siang hari di dalam ruangan (derajat cerah ISO)) dan noda (SNI ISO 5350-1:2014 - Pulp - Cara uji noda dan shives - Bagian 1 : Pemeriksaan lembaran laboratorium menggunakan transmisi cahaya).

\section{Hasil dan Pembahasan}

Hasil pengamatan morfologi serat kedua spesies agave disajikan pada Tabel 1. Kedua spesies agave memiliki panjang serat lebih dari $4 \mathrm{~mm}$ sehigga termasuk dalam serat panjang sesuai SNI 0698:2010 - Pulp kraft putih kayujarum (NBKP), yaitu minimal 2,1 mm. Agave sisalana memiliki serat yang lebih panjang dan lebih sempit dari $A$. cantala. Namun demikian serat $A$. sisalana maupun A. cantala lebih panjang dari serat beberapa jenis serat non-kayu seperti beberapa jenis bambu, kenaf, maupun kayu jarum (softwood) seperti pinus dan lebih pendek dari serat daun nanas seperti disajikan pada Tabel 1. Serat yang lebih panjang akan menghasilkan kekuatan kertas yang lebih baik terutama kekuatan sobek (Kardiansyah and Sugesty, 2014). Sementara itu, kedua spesies agave mempunyai dinding yang lebih tebal dibanding serat $A$. sisalana dalam penelitian Fidelis et al. (2013) dan serat non-kayu lainnya kecuali bambu. Bentuk serat yang berdinding tebal lebih sulit berubah bentuk sehingga mempersulit pemipihan serat dan terbentuknya ikatan antar serat (Haroen, 2016). Ikatan antar serat yang lemah cenderung menghasilkan kertas yang memiliki indeks retak dan indeks tarik yang lebih rendah (Dutt and Tyagi, 2011).

Nilai turunan dimensi serat dihitung dari hasil pengukuran morfologi serat. Selain dari morfologi serat, sifat fisik lembaran pulp yang akan dihasilkan juga dapat diperkirakan dari nilai turunan dimensi serat. Tabel 2 menunjukkan nilai turunan dimensi serat $A$. sisalana, A. cantala, dan beberapa serat panjang lainnya. A. cantala memiliki nilai bilangan Runkel dan Muhlstep ratio lebih tinggi dari $A$. sisalana. Hal tersebut menunjukkan bahwa $A$. cantala memiliki permukaan serat yang lebih lebar yang memungkinkan lebih banyak ikatan antar serat. Ikatan serat yang baik akan menghasilkan indeks tarik dan indeks retak lebih baik (Dutt and Tyagi, 2011; Haroen, 2016). Selain itu, serat $A$. cantala juga memiliki nilai kekakuan dan kelemasan yang lebih baik dibanding serat A. sisalana. Serat dengan nilai kekakuan lebih rendah dan kelemasan lebih tinggi memiliki dinding sel yang lebih tipis sehingga serat lebih mudah berubah bentuk. Serat yang mudah berubah bentuk akan menghasilkan persinggungan antar permukaan

Tabel 1. Morfologi Serat A. sisalana, A. cantala, dan Beberapa Serat Panjang Lainnya

\begin{tabular}{lccccc}
\hline Spesies & $\begin{array}{c}\text { Panjang serat } \\
(\mathrm{mm})\end{array}$ & $\begin{array}{c}\text { Lebar serat } \\
(\mu \mathrm{m})\end{array}$ & $\begin{array}{c}\text { Diameter } \\
\text { lumen }(\mu \mathrm{m})\end{array}$ & $\begin{array}{c}\text { Tebal dinding } \\
\text { sel }(\mu \mathrm{m})\end{array}$ & Referensi \\
\hline A. sisalana & 4,87 & 23,99 & 8,82 & 7,59 & - \\
A. cantala & 4,19 & 24,03 & 11,48 & 6,28 & - \\
A. sisalana & - & - & 8,2 & 2,6 & Fidelis et al. $(2013)$ \\
Bambu & $2,30-4,69$ & $21-30$ & $4-8$ & $7-13$ & Fatriasari and Hermiati (2008) \\
Kenaf $^{\text {a }}$ & $2,28-2,96$ & $21,26-24,16$ & $7,99-11,74$ & $6,18-6,91$ & H'ng et al. $(2009)$ \\
Pinus ${ }^{b}$ & 2,19 & 32,4 & 15,15 & 2,25 & Sable et al. $(2012)$ \\
Daun nanas & 6,12 & 23,00 & 13,90 & 3,50 & Indrawan et al. $(2015)$ \\
\hline
\end{tabular}

Keterangan : ${ }^{a}$ serat kulit; ${ }^{b}$ pulp, rata-rata dari 2 spesies 
serat lebih luas sehingga pada akhirnya menghasilkan lembaran dengan kerapatan kertas tinggi, porositas rendah, serta kekuatan tarik dan retak tinggi (Haroen, 2016). Namun A. sisalana memiliki kelangsingan serat yang lebih tinggi dari $A$. cantala. Nilai kelangsingan lebih tinggi menunjukkan serat $A$. sisalana tersusun lebih rapat dan cenderung lebih lentur sehingga akan membentuk jalinan lebih baik dan menghasilkan lembaran dengan kekuatan sobek lebih tinggi (Fatriasari and Hermiati, 2008; Haroen, 2016).

Bila dibandingkan dengan serat kenaf dalam penelitian Kardiansyah and Sugesty (2014) dan serat bambu dalam penelitian Fatriasari and Hermiati (2008), serat $A$. sisalana dan A. cantala dalam penelitian ini secara umum memiliki nilai turunan dimensi yang lebih baik. Sementara itu, serat daun nanas dalam penelitian Indrawan et al. (2015) memiliki nilai turunan dimensi lebih baik dari A. sisalana dan A. cantala (Tabel 2).

Serat agave merupakan serat lignoselulosa yang terdiri dari komponen utamanya yaitu selulosa, lignin, dan hemiseluosa (pentosan) serta komponen lainnya seperti abu dan kadar sari. Tabel 3 menyajikan komposisi komponen kimia dari A. sisalana, A. cantala, dan beberapa serat panjang lainnya. A. sisalana memiliki komposisi komponen kimia yang lebih baik dari A. cantala karena memiliki kandungan selulosa alfa dan holoselulosa yang lebih tinggi serta lignin, kadar abu, kadar sari, kelarutan $1 \% \mathrm{NaOH}$, kelarutan air panas dan air dingin lebih rendah.

Selulosa merupakan komponen utama serat. SNI 01-1303-1989 - Cara Uji Kadar Holoselulosa Kayu mendeskripsikan selulosa sebagai polisakarida linier yang terdiri atas satuan anhidroglukosa dengan ikatan 1-4 $\beta$ glukosidik yang pada hidrolisa kondisi asam menghasilkan D-glukosa. Selulosa berperan sangat penting bagi karakteristik kertas yang akan dibentuk. Sumber utama ikatan antar serat di dalam kertas berasal dari daya tarik antar molekul selulosa dari permukaan serat yang berbeda (Håkan Karlsson, 2006). Kandungan selulosa $A$. sisalana $(63,78 \%)$ sedikit lebih tinggi dari A. cantala (62,95\%).

Kandungan lignin dalam serat $A$. cantala hampir dua kali lebih tinggi dari serat $A$. sisalana namun masih jauh lebih rendah dari serat lainnya. Keberadaan lignin menyebabkan warna pulp menjadi lebih gelap dan mempunyai kekuatan lembaran yang rendah (Håkan Karlsson, 2006; Haroen, 2016). Menurut SNI 8429:2017 - Lignin tidak larut asam dalam kayu dan pulp, lignin didefinisikan sebagai senyawa aromatik yang berbentuk amorf yang berfungsi sebagai perekat antar sel dan terdapat dalam lamela tengah dan dinding sel. Bahan baku yang mempunyai konsentrasi lignin rendah akan turut menghemat dalam proses karena memerlukan kondisi pulping yang lebih ringan dan lebih sedikit bahan kimia dalam proses pemutihan pulp.

Menurut SNI 14-1304-1989 Cara Uji Kadar Pentosan dalam Kayu, pentosan terdiri atas rantai pentosan terutama xylan dan sedikit araban yang merupakan bagian dari karbohidrat yang bukan selulosa. Pentosan merupakan bagian dari hemiselulosa. Hemiselulosa dalam bahan baku dapat dengan mudah hilang oleh proses pemasakan secara kimia. Hemiselulosa juga berperan penting pada proses pembuatan kertas untuk membangun ikatan-ikatan antar serat. Selain perannya secara langsung dalam membentuk ikatan antar serat, hemiselulosa juga berperan mempengaruhi kemampuan serat

Tabel 2. Nilai Turunan Dimensi Serat A. sisalana, A. cantala, dan Beberapa Serat Panjang Lainnya

\begin{tabular}{lcccccc}
\hline Spesies & $\begin{array}{c}\text { Bilangan } \\
\text { runkel }\end{array}$ & $\begin{array}{c}\text { Muhlstep } \\
\text { ratio }(\%)\end{array}$ & Kekakuan & Kelemasan & Kelangsingan & Referensi \\
\hline A. sisalana & 1,82 & 84,49 & 0,31 & 0,38 & 204,40 & - \\
A. cantala & 1,15 & 77,39 & 0,27 & 0,47 & 176,14 & - \\
Bambu & $1,67-5,94$ & $90,85-97,93$ & $0,31-0,43$ & $0,14-0,38$ & $89,09-190,85$ & $\begin{array}{c}\text { Fatriasari and Hermiati } \\
(2008)\end{array}$ \\
Kenaf a & 1,72 & 86,48 & 0,32 & 0,37 & 150,94 & $\begin{array}{c}\text { Kardiansyah and Sugesty } \\
(2014)\end{array}$ \\
Daun nanas & 0,50 & 10,35 & 0,15 & 0,60 & 266,10 & Indrawan et al. (2015) \\
\hline
\end{tabular}

Keterangan : ${ }^{a}$ serat kulit 
untuk menyerap air (Håkan Karlsson, 2006). Kadar pentosan $A$. cantala $(23,13 \%)$ lebih tinggi dibanding $A$. sisalana $(20,91 \%)$ namun keduanya masih jauh lebih tinggi dibanding $A$. americana $(15,67 \%)$ (Mylsamy and Rajendran, 2010) dan kenaf (17,6\%) (Jonoobi et al., 2009).

SNI 01-1303-1989 Cara Uji Kadar Holoselulosa Kayu mendefinisikan holoselulosa adalah bagian serat yang telah bebas sari dan lignin, terdiri atas selulosa dan hemiselulosa. Holoselulosa berwarna putih sampai kekuningkuningan. Kadar holoselulosa serat $A$. sisalana $(94,35 \%)$ sedikit lebih tinggi dari serat $A$. cantala $(93,94 \%)$. Namun kadar holoselulosa serat kedua spesies lebih tinggi dari bambu $(73,32-$ 83,75\%) (Fatriasari and Hermiati, 2008) dan kayu Araucaria cunninghamii (73,77\%) (Setiadi, Susanto and Fauzi, 2015).

Kadar abu A. sisalana jauh lebih rendah dari A. cantala. Jumlah kadar abu akan mempengaruhi konsumsi alkali dalam proses pulping. Selain itu, kadar abu yang tinggi akan mempersulit proses pemulihan larutan pemasak serta menyebabkan masalah pada proses penanganan bahan baku, pencucian pulp, dan beating pulp (Dutt and Tyagi, 2011). Namun dibandingkan dengan bahan baku serat lainnya dalam Tabel 2, kedua spesies agave memiliki kadar abu yang lebih rendah.

Kadar sari serat $A$. sisalana $(0,18 \%)$ lebih rendah dibanding serat $A$. cantala $(0,63 \%)$. Sementara itu, kadar sari dalam serat lainnya jauh lebih tinggi dari kedua spesies agave tersebut. Menurut (Fatriasari and Hermiati (2008), kadar sari dalam alkohol benzena berupa resin, lemak, lilin, dan tanin. Gutiérrez, Rodríguez and del Río (2008) menemukan bahwa beberapa kadar sari lipofilik yang terkandung dalam $A$. sisalana adalah asam lemak yang terdiri dari $\alpha$ - dan $\omega$ asam lemak hidroksi, lemak alkohol, sterol bebas, alkana, ester asam ferulic seri alkohol rantai panjang dan $\omega$-asam lemak hidroksi, steroid hidrokarbon dan keton, monogliserida, aldehida, lilin, sterol glikosida, digliserida dan sterol ester. Keberadaan minyak dan lemak dalam kadar sari akan mempersulit delignifikasi, memperbesar konsumsi alkali, serta mengurangi kekuatan ikatan antar serat (Fatriasari and Hermiati, 2008).

Konsentrasi zat terlarut dalam natrium hidroksida satu persen, air panas, dan air dingin serat $A$. sisalana lebih rendah dari serat $A$. cantala. Dalam SNI 14-1838-1990 - Cara uji kelarutan kayu dan pulp dalam larutan natrium hidroksida satu persen dijelaskan bahwa komponenkomponen yang larut dalam $\mathrm{NaOH}$ satu persen adalah senyawa anorganik dan organik antara lain karbohidrat dengan berat molekul rendah, zat warna, kinon, tanin, dan sebagian lignin. SNI 01-1305-1989 - Kayu - Cara uji kelarutan dalam air dingin dan air panas menyebutkan komponen-komponen yang larut dalam air panas meliputi garam-garam organik, garam-garam anorganik, pektin, tanin, pigmen, siklitol, gula, gum, galaktan, polisakarida, dan komponen lain yang terhidrolisa. Sementara komponenkomponen yang larut dalam air dingin meliputi garam-garam organik, garam-garam anorganik, bahan-bahan menyerupai pektin, tanin, pigmen, siklitol, gula, gum, dan galaktan.

Tabel 3. Komposisi Komponen Kimia (\%) Serat A. sisalana, A. cantala, dan Beberapa Serat Panjang Lainnya

\begin{tabular}{|c|c|c|c|c|c|c|c|c|c|}
\hline Spesies & $\begin{array}{c}\text { Selulosa } \\
\text { alfa }\end{array}$ & Lignin & Pentosan & Holoselulosa & $\begin{array}{c}\text { Kadar } \\
\text { abu }\end{array}$ & Kadar sari & $\begin{array}{l}\text { Kelarutan } \\
\mathrm{NaOH} 1 \%\end{array}$ & $\begin{array}{c}\text { Kelarutan } \\
\text { air panas }\end{array}$ & $\begin{array}{l}\text { Kelarutan } \\
\text { air dingin }\end{array}$ \\
\hline A. sisalana & 63,78 & 4,76 & 20,91 & 94,35 & 0,59 & 0,18 & 11,73 & 0,36 & 1,30 \\
\hline A. cantala & 62,95 & 7,94 & 23,13 & 93,94 & 0,84 & 0,63 & 14,48 & 1,52 & 1,96 \\
\hline A. americana ${ }^{\text {a }}$ & $68,42^{*}$ & 4,85 & $15,67^{* *}$ & - & - & - & - & - & - \\
\hline Bambu ${ }^{b}$ & & $\begin{array}{l}30,01- \\
36,88\end{array}$ & - & $73,32-83,75$ & - & $0,91-1,52$ & $18,01-24,06$ & $5,29-7,19$ & $2,39-5,67$ \\
\hline Kenaf $^{c}$ & $63,5^{*}$ & 12,7 & $17,6^{* *}$ & - & 2,2 & 4,0 & - & - & - \\
\hline $\begin{array}{l}\text { Araucaria } \\
\text { cunninghamii }^{\mathrm{d}}\end{array}$ & $46,39^{*}$ & 30,56 & - & 73,33 & - & - & - & 1,34 & - \\
\hline Pinus ${ }^{e}$ & $49,0^{*}$ & 26,75 & - & - & 0,3 & 2,75 & - & - & - \\
\hline
\end{tabular}

Keterangan : ${ }^{a}$ Mylsamy and Rajendran (2010); ${ }^{b}$ Fatriasari and Hermiati (2008); ${ }^{c}$ Jonoobi et al. (2009); ${ }^{d}$ Setiadi, Susanto and Fauzi (2015); ${ }^{e}$ Sable et al. (2012); " Selulosa; ${ }^{* *}$ Hemiselulosa 
Pembuatan pulp dilakukan menggunakan metode soda dan kraft dengan karakteristik pulp disajikan dalam Gambar 1. Meskipun metode soda menghasilkan rendemen lebih tinggi namun menghasilkan bilangan Kappa yang juga lebih tinggi dibandingkan dengan metode kraft. Selain menggunakan natrium hidroksida seperti dalam metode soda, metode kraft menggunakan natrium sulfida. Peningkatan konsentrasi alkali karena keberadaan natrium sulfida mampu menyebabkan penurunan rendemen karena degradasi selulosa pulp (Chong and Chiang, 2014). Berbeda dengan penelitian pemasakan pulp oleh Fatriasari and Risanto (2011) pada kayu sengon yang memperoleh rendemen lebih tinggi pada sulfiditas yang lebih tinggi dan konsentrasi alkali yang sama. Sementara itu, pemasakan pulp serat Agave tequilana menggunakan proses asam (organosolv) menghasilkan rendemen selulosa lebih tinggi dibanding proses basa $(\mathrm{NaOH})$ (Prieto-Garcia et al., 2018)

Bilangan Kappa yang tinggi menunjukkan kadar lignin dalam pulp yang masih tinggi. Menurut Håkan Karlsson (2006), penentuan bilangan Kappa berfungsi untuk mengetahui derajat delignifikasi pada proses pemasakan dan menentukan bahan kimia yang diperlukan dalam proses pemutihan pulp. Pulp serat $A$. sisalana mempunyai nilai bilangan Kappa lebih tinggi meskipun serat $A$. cantala berkadar lignin lebih tinggi.

Pulp A. sisalana mempunyai nilai viskositas 19,6\% lebih tinggi dari $A$. cantala dan proses soda menghasilkan viskositas $37,2 \%$ lebih tinggi dibanding proses kraft. Viskositas pulp mengindikasikan derajat polimerisasi selulosa (Håkan Karlsson, 2006). Derajat polimerisasi selulosa dihitung dari nilai viskositas intrinsik. Derajat polimerisasi selulosa serat kedua spesies agave hampir sama pada masing-masing proses soda dan kraft. Namun demikian, proses soda menghasilkan derajat polimerisasi $26,4 \%$ lebih tinggi dibanding proses kraft.

Tabel 4 menyajikan hasil pengukuran sifat optik dan fisik lembaran pulp serat $A$. sisalana dan A. cantala. Lembaran pulp serat $A$. cantala lebih cerah dibanding lembaran pulp $A$. sisalana dan proses kraft menghasilkan lembaran yang lebih cerah dari proses soda. Serat $A$. cantala dan proses kraft menghasilkan lembaran yang lebih cerah karena kadar lignin yang lebih rendah yang ditunjukkan pada nilai bilangan Kappa yang lebih rendah (Tabel 4). Pada seluruh lembaran pulp tidak ditemukan noda. Nilai derajat cerah $(87,35-$ $89,90 \%$ ISO $)$ dan noda $\left(0 \mathrm{~mm}^{2} / \mathrm{m}^{2}\right)$ seluruh perlakuan memenuhi kriteria SNI 0698:2010 - Pulp kraft putih kayujarum (NBKP) yaitu berturut-turut minimal $85 \%$ ISO dan maksimal 5 $\mathrm{mm}^{2} / \mathrm{m}^{2}$

Berbanding terbalik dengan derajat cerah, secara umum $A$. sisalana dan proses soda menghasilkan lembaran dengan kekuatan lebih tinggi. Indeks sobek tertinggi diperoleh dari lembaran pulp $A$. sisalana dengan pemasakan soda yaitu sebesar $18,20 \mathrm{mN} \cdot \mathrm{m}^{2} / \mathrm{g}$ dan nilai terendah pada lembaran $A$. cantala dengan pemasakan kraft yaitu $10,90 \mathrm{mN} \cdot \mathrm{m}^{2} / \mathrm{g}$. Lembaran pulp $A$. sisalana memiliki indeks sobek yang lebih tinggi karena didukung oleh serat yang lebih panjang dan
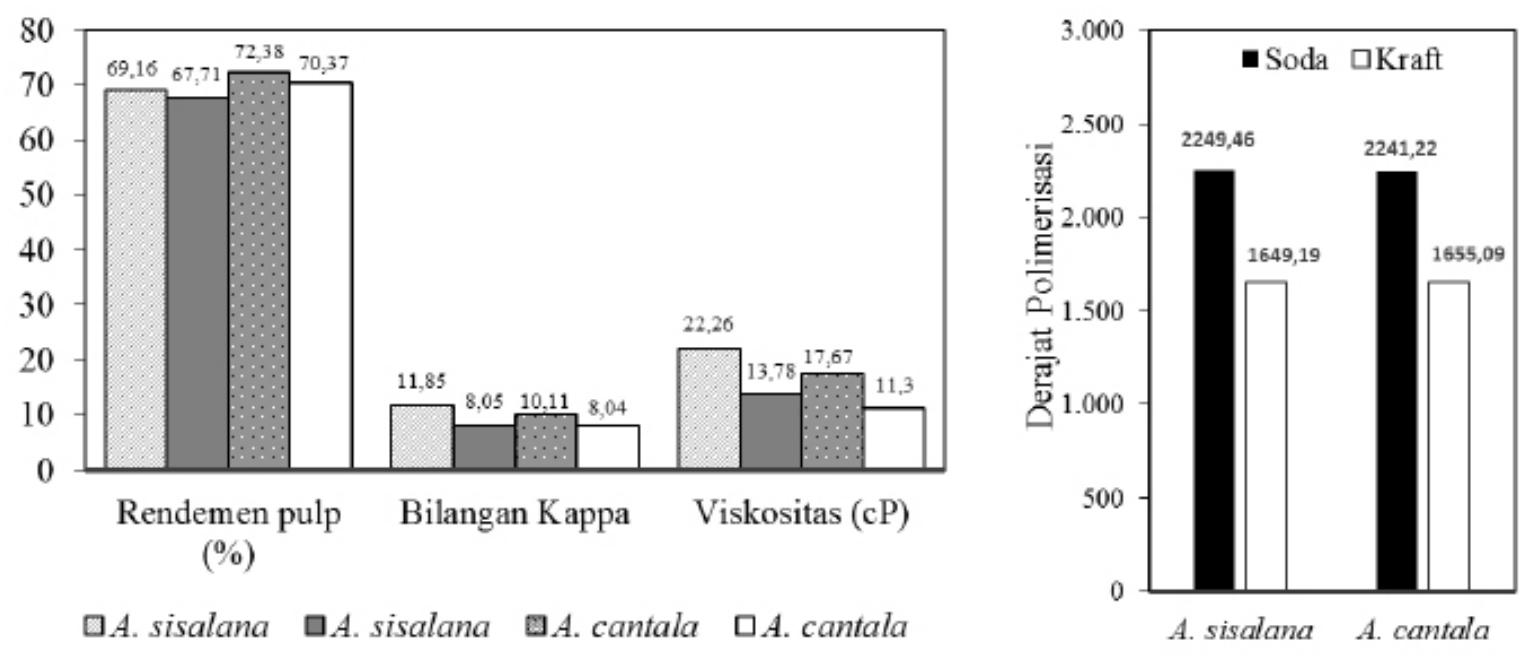

Gambar 1. Karakteristik Pulp Serat A. sisalana dan A. cantala Hasil Pemasakan Proses Soda dan Kraft 
Tabel 4. Sifat Optik dan Fisik Lembaran Pulp dari Serat A. sisalana dan A. cantala Hasil Pemasakan Proses Soda dan Kraft

\begin{tabular}{|c|c|c|c|c|c|c|}
\hline \multirow[b]{2}{*}{ Spesies } & \multirow[b]{2}{*}{$\begin{array}{c}\text { Metode } \\
\text { pemasakan }\end{array}$} & \multicolumn{2}{|c|}{ Sifat optik } & \multicolumn{3}{|c|}{ Sifat fisik } \\
\hline & & $\begin{array}{c}\text { Derajat cerah } \\
\text { (\% ISO) }\end{array}$ & $\begin{array}{c}\text { Noda } \\
\left(\mathrm{mm}^{2} / \mathrm{m}^{2}\right)\end{array}$ & $\begin{array}{l}\text { Indek sobek } \\
\left(\mathrm{mN} \cdot \mathrm{m}^{2} / \mathrm{g}\right)\end{array}$ & $\begin{array}{c}\text { Indeks retak } \\
\left(\mathrm{kPa} \cdot \mathrm{m}^{2} / \mathrm{g}\right)\end{array}$ & $\begin{array}{l}\text { Indeks tarik } \\
(\mathrm{Nm} / \mathrm{g})\end{array}$ \\
\hline \multirow{2}{*}{$\begin{array}{l}A . \\
\text { sisalana }\end{array}$} & Soda & 87,35 & 0,00 & 18,20 & 4,80 & 55,40 \\
\hline & Kraft & 88,00 & 0,00 & 12,95 & 3,85 & 48,45 \\
\hline \multirow{2}{*}{ A. cantala } & Soda & 89,75 & 0,00 & 13,30 & 3,85 & 45,70 \\
\hline & Kraft & 89,90 & 0,00 & 10,90 & 3,65 & 46,95 \\
\hline \multicolumn{2}{|c|}{ Standar SNI NBKP* } & Min. 85 & Maks. 5 & Min. 8 & Min. 5 & $\operatorname{Min} 80$ \\
\hline
\end{tabular}

Keterangan : * SNI 0698:2010

nilai kelangsingan yang lebih tinggi dibanding serat $A$. cantala. Hasil tersebut sesuai dengan penelitian Kardiansyah and Sugesty (2014) yang memperoleh kekuatan sobek lebih tinggi dari serat kulit kenaf karena seratnya lebih panjang dibanding serat bagian lainnya. Nilai indeks sobek seluruh perlakuan memenuhi kriteria SNI 0698:2010 - Pulp kraft putih kayujarum (NBKP) yaitu minimal $8 \mathrm{mN} \cdot \mathrm{m}^{2} / \mathrm{g}$.

Nilai indeks retak dan tarik lembaran $A$. sisalana lebih tinggi dibanding $A$. cantala meskipun mempunyai nilai bilangan Runkel, Muhlstep ratio, kekakuan, dan kelemasan lebih baik dibanding A. sisalana. Menurut Dutt and Tyagi (2011), terdapat faktor-faktor lain seperti formasi dan densitas serat, luas daerah ikatan, orientasi serat, geometri serat, dan kekuatan serat itu sendiri sehingga tren hubungan antara morfologi serat dan sifat fisik lembaran dapat berubah. Sementara itu, metode pemasakan soda menghasilkan lembaran dengan indeks retak lebih tinggi pada kedua spesies agave dan indeks tarik lebih tinggi pada A. sisalana. Nilai indeks retak dan indeks tarik tidak memenuhi standar SNI NBKP namun masih memenuhi standar nilai SNI 6107:2009 - Pulp kraft putih kayudaun (LBKP) yaitu minimal $2,5 \mathrm{kPa} \cdot \mathrm{m}^{2} / \mathrm{g}$ untuk indeks retak dan minimal $80 \mathrm{Nm} / \mathrm{g}$ untuk indeks tarik.

\section{Kesimpulan}

Hasil analisis morfologi serat, komponen kimia, karakteristik pulp, serta sifat fisik dan sifat optik lembaran pulp menyatakan bahwa serat $A$. sisalana dan A. cantala berpotensi menjadi bahan baku kertas. Serat A. sisalana menghasilkan lembaran pulp dengan kekuatan sobek, tarik, dan retak lebih tinggi dibanding serat $A$. cantala.
Metode pemasakan soda pada serat $A$. sisalana dan A. cantala menghasilkan rendemen pulp, derajat polimerisasi selulosa, dan kekuatan fisik lebih baik dibanding metode kraft. Sifat optik dan kekuatan sobek lembaran pulp dari kedua spesies agave memenuhi standar nilai SNI Pulp Kraft Putih Kayujarum (NBKP), namun kekuatan retak dan kekuatan tarik hanya memenuhi standar nilai SNI Pulp Kraft Putih Kayudaun (LBKP).

\section{Daftar Pustaka}

Balittas (2016) Laporan Akhir RPTP/RDHP Tahun Anggaran 2016. Malang.

Balittas and PT.SBS (2016) Klon Unggul Sisal untuk Menghijaukan Pulau Sumbawa: Usulan Pelepasan Klon H 11648 sebagai Varietas Unggul Sisal di Sumbawa. Malang

Chong, E. and Chiang, L. K. (2014) 'Comparative study between organosolv pulping using different concentrations of ethanol and kraft pulping of Acacia hybrid', Agriculture and Forestry, 60(2), pp. 47-57.

Dutt, D. and Tyagi, C. H. (2011) 'Comparison of various eucalyptus species for their morphological, chemical, pulp and paper making characteristics', Indian Journal of Chemical Technology, 18, pp. 145-151.

Fatriasari, W. and Hermiati, E. (2008) 'Analisis morfologi serat dan sifat fisis-kimia pada enam jenis bambu sebagai bahan baku pulp dan kertas', Jurnal Ilmu dan Teknologi Hasil Hutan, 1(2), pp. 67-72.

Fatriasari, W. and Risanto, L. (2011) 'Sifat Pulp Kayu Sengon (Paraserianthes falcataria): Perbedaan Konsentrasi Bahan Pemasak dan Tahap Pemutihan', Widyariset, 14(3), pp. 589-598. 
Fidelis, M. E. A. et al. (2013) 'The effect of fiber morphology on the tensile strength of natural fibers', Journal of Materials Research and Technology, 2(2), pp. 149-157.

Gutiérrez, A., Rodríguez, I. M. and del Río, J. C. (2008) 'Chemical composition of lipophilic extractives from sisal (Agave sisalana) fibers', Industrial Crops and Products, 28, pp. 81-87. doi: 10.1016/j.indcrop.2008.01.008.

H'ng, P. et al. (2009) 'Anatomical Structures and Fiber Morphology of New Kenaf Varieties', Asian Journal of Scientific Research, 2(3), pp. 161-166.

Håkan Karlsson (2006) Fibre Guide: Fiber Analysis and Process Aplications in The Pulp and Paper Industry. AB Lorentzen \& Wettre Sweden.

Haroen, W. K. (2016) Teknologi Serat Bahan Baku Pulp Kertas. Bandung: Agung Ilmu.

Hurter, R. W. (2001) 'Sisal fibre: market opportunities in the pulp and paper industry', Technical Paper, 14, pp. 61-74.

Indrawan, D. A. et al. (2015) 'Pembuatan Pulp untuk Kertas Bungkus dari Bahan Serat Alternatif', Jurnal Penelitian Hasil Hutan, 33(4), pp. 283-302.

Jamil, A. H., Parnidi and Yogi, Y. A. (2017) 'Mengenal Perbedaan Tiga Spesies Agave', Warta Penelitian dan Pengembangan Pertanian, 39(4), pp. 5-6.

Jonoobi, M. et al. (2009) 'Chemical composition, crystallinity, and thermal degradation of bleached and unbleached kenaf bast (Hibiscus cannabinus) pulp and nanofibers', BioResources, 4(2), pp. 626-639. .
Kardiansyah, T. and Sugesty, S. (2014) 'Karakteristik pulp kimia mekanis dari kenaf (Hibiscus cannabinus L .) untuk kertas lainer', Jurnal Selulosa, 4(1), pp. 37-46.

Mylsamy, K. and Rajendran, I. (2010) 'Investigation on physio-chemical and mechanical properties of raw and alkalitreated Agave americana fiber', Journal of Reinforced Plastics and Composites, 29(19), pp. 2925-2935.

Prieto-Garcia, F. et al. (2018) 'Obtaining and optimization of cellulose pulp from leaves of Agave tequilana Weber Var. Blue preparation of handmade craft paper', Waste and Biomass Valorization.

Sable, I. et al. (2012) 'Comparison of The Properties of Wood and Pulp Fibers from Lodgepole Pine (Pinus contorta) and Scots Pine (Pinus sylvestris)', BioResources, 7(2), pp. 1771-1783.

Santoso, B. (2009) 'Peluang pengembangan agave sebagai sumber serat alam', Perspektif, 8(2), pp. 84-95.

Setiadi, D., Susanto, M. and Fauzi, M. A. (2015) 'Analisa Kimia Kayu pada Tanaman Araucaria cunninghamii Aiton ex D.Don untuk Bahan Baku Pulp', Jurnal Pemuliaan Tanaman Hutan, 9(1), pp. 53-60.

Utomo, B. I., Dahal, K. R. and Umali, B. E. (2003) 'Agave cantala Roxb.', in Brink, M. and Escobin, R. P. (eds) Plant Resources of South-East Asia No 17. Fiber plants. Backhyus Publishers, Leiden, the Netherlands, pp. 6468. 